\title{
Randomised trial of a vibrating bladder stimulator - the time to pee study
}

\author{
P Davies, ${ }^{1}$ R Greenwood, ${ }^{2}$ J Benger ${ }^{3}$
}

${ }^{1}$ Emergency Department, Bristol Children's Hospital, Bristol;

${ }^{2}$ Research and Development Support Unit, United Bristol Healthcare Trust, Bristol;

${ }^{3}$ Faculty of Health and Social Care, University of the West of England, Bristol

Correspondence to:

Patrick Davies, Emergency

Department, Bristol Children's

Hospital, Bristol, UK:

daviespatrick@hotmail.com

Accepted 5 December 2007

Published Online First

11 January 2008

\section{ABSTRACT}

This randomised, non-blinded study evaluated a vibrating bladder stimulator to facilitate collection of a urine sample from pre-continent children. The use of a bladder stimulator produced no significant time improvements in any of the analysed parameters ( $n=97)$. We identify a population of patients who may benefit from some form of bladder stimulation.

The collection of urine from young children is essential, frustrating and upsetting for both the child and the carer. There is currently no ideal solution that addresses the problems of speed, convenience, effect on the child, accuracy and risk of complications.

The clean catch sample is commonly used as a non-invasive, low contamination compromise. ${ }^{12}$ However, this often leaves patients and parents with a distressingly long wait.

In our view, instantly available clean catch samples would be the ideal collection method. We sourced a commercially available bladder stimulator (Queen Square Bladder Stimulator, Malem Medical, Nottingham, UK). This is a hand-held battery-operated $60 \mathrm{~Hz}$ vibrating disk. Previous studies of this device in adults have shown symptom improvement and decreased residual bladder volumes in adults with multiple sclerosis. ${ }^{3}$ We hypothesised that this device might stimulate urine flow in pre-continent children.

\section{METHOD}

This was a randomised, non-blinded study. Inclusions were all pre-continent children attending a single children's emergency department who needed a urine sample. Excluded were all children who did not need a bacteriological sample, were too unwell, did not have a parent with them, had insufficient parental understanding owing to language barriers or had neurological or anatomical abnormalities affecting their voiding.

Ethical approval was granted. The study was assessed by the Research Governance Unit and study conduct was found to be good. Informed written consent was obtained by a trained researcher before randomisation of the treatment using sealed, opaque envelopes into two equal groups. The "advice" group were given a sheet detailing methods of stimulating urine flow by massage, tapping the abdomen and offering drinks. Those in the "device" group were shown how to operate the stimulator and advised to use this for 1 min out of every 5 , as well as offering drinks.

The study was designed to detect a reduction in time to pass urine of 20 minutes, with a total sample of 96 children. Data were analysed on an intention to treat basis using SPSS version 12 .

Differences between the two groups were assessed using $\chi^{2}$ testing for the binary variable (wait time greater or less than $1 \mathrm{~h}$ ) and log rank testing for the survival analysis.

\section{RESULTS}

Data from 110 patients were randomised, from which we obtained 97 valid data points (48 "advice", 49 "device"). Baseline characteristics for the two groups are shown in table 1.

Boys (1 h $2 \mathrm{~min}$ ) had no difference in the average time to pass urine to girls ( $1 \mathrm{~h} 4 \mathrm{~min}$ ). There was a non-significant trend to earlier urine production in younger children (2 min $14 \mathrm{~s}$ slower per month of additional age). $80 \%$ passed urine in under $2 \mathrm{~h}$. The results are shown in table 2.

A Kaplan-Meier plot (fig 1) suggests a threegroup model of urine voiding. In the first $15 \mathrm{~min}$ approximately $30 \%$ obtained a sample, with or without the stimulator. Between $15 \mathrm{~min}$ and $1 \mathrm{~h}$ 40 min there was a splitting of the two curves, with the "device" group obtaining a sample earlier than the "advice" group. The $\mathrm{T}_{50}$ is 30 min earlier in the "device" than the "advice group" within this time period. Beyond $1 \mathrm{~h} 40 \mathrm{~min}$, however, the "advice" and "device" groups converge again: these are presumably dehydrated patients who will not pass urine for many hours.

Five parents commented on on their child being more upset while using the device, and two commented on a transient red mark on the child's skin.

\section{DISCUSSION}

A solution to the urinary collection dilemma has yet to be found. Our study shows that there is no significant improvement in waiting times with a $60 \mathrm{~Hz}$ external bladder vibrator. There are, however, some disadvantages to the device that may have detracted from its efficacy. It is noisy and has an abrupt start that can frighten children. The vibrating disk is large compared with a baby's abdomen. Some parents allocated to the vibrator chose not to use it owing to these problems.

It seems unlikely that simple vibration is the ideal solution to urinary stimulation, and we found no previous relevant research. Some studies in patients with neurogenic bladders have used electrical stimuli to obtain urine flow. ${ }^{5}$ However, we feel that "electric shocks" are unlikely to be accepted by parents.

The use of thermal stimuli is another possibility: cold has long been associated with the need to pass urine. There is, however, the risk of cold burns to 
Table 1 Baseline characteristics of the two randomisation groups

\begin{tabular}{|c|c|c|c|c|}
\hline \multirow{2}{*}{\multicolumn{2}{|c|}{ Percentage male }} & \multirow{2}{*}{$\begin{array}{l}\text { Advice group } \\
42 \%\end{array}$} & \multirow{2}{*}{$\begin{array}{l}\text { Device Group } \\
\mathbf{5 4} \% \\
\end{array}$} & \multirow{2}{*}{$\frac{p \text { Value }}{0.25}$} \\
\hline & & & & \\
\hline \multicolumn{2}{|c|}{ Age: range, mean (months) } & $0.5-35,10.72$ & $1-31,10.76$ & 0.98 \\
\hline \multirow{4}{*}{$\begin{array}{l}\text { Presenting } \\
\text { complaints }\end{array}$} & Fever & 29 & 23 & 0.40 \\
\hline & Vomiting & 10 & 9 & 0.82 \\
\hline & Unwell & 3 & 5 & 0.48 \\
\hline & Other & 6 & 12 & 0.16 \\
\hline
\end{tabular}

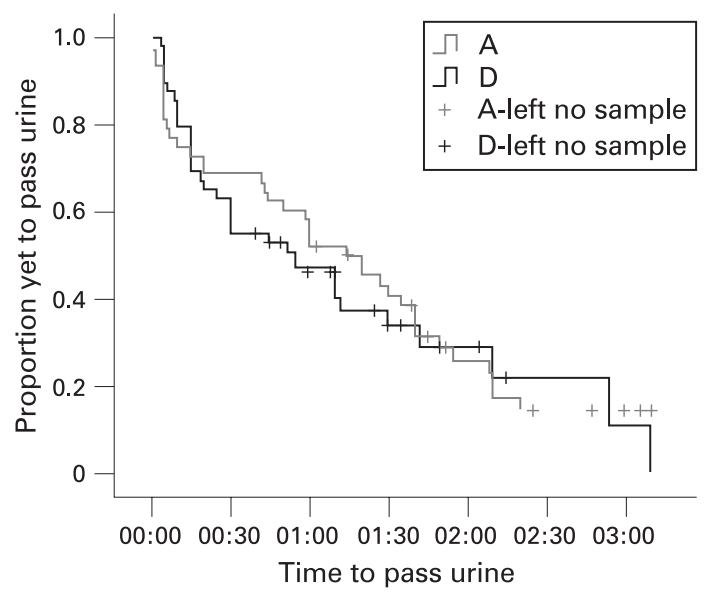

Figure 1 Kaplan-Meier plot of time to pass urine and the proportion who have yet to do so.

sensitive skin, and young children are likely to equate cold and pain as similar discomforts.

The three-group trend shown in the Kaplan-Meier plot identifies a potential population of children who might be stimulated to pass urine sooner, if the ideal method was identified.

\section{CONCLUSION}

Simple external $60 \mathrm{~Hz}$ abdominal vibration does not cause a significant reduction in the time to pass urine in a pre-continent child.
Table 2 Results

\begin{tabular}{lrrr}
\hline & Advice & Device & p Value \\
\hline $\begin{array}{l}\text { Minutes to pass urine or leave department } \\
\text { (mean } \pm 95 \% \mathrm{Cl} \text { ) }\end{array}$ & $71 \pm 15$ & $53 \pm 12$ & 0.20 \\
Percentage waiting for less than 1 h & $42 \%$ & $53 \%$ & 0.15 \\
Number leaving without a sample & 10 & 15 & 0.27 \\
\hline
\end{tabular}

\section{What is already known on this topic}

- Urine collection in children is difficult and time consuming.

- Every method of urine collection has significant flaws.

\section{What this study adds}

- Abdominal $60 \mathrm{~Hz}$ vibration does not have a significant effect on urine collection times in pre-continent children.

- The mean time spent waiting for a urine sample is $1 \mathrm{~h}$.

Acknowledgements: We thank the Academic Department of Emergency Care in Bristol, which funded this study. The Academic Department is supported by the Anthony Hopkins Memorial Prize, awarded by the College of Emergency Medicine.

Funding: We have received no monetary or material support from the makers of the device.

Competing interests: None.

\section{REFERENCES}

1. Liaw L, Nayar D, Pedler S, et al. Home collection of urine for culture from infants by three methods: survey of parents' preferences and bacterial contamination rates. BMJ 2000;320:1312-3.

2. Hardy JD, Furnell PM, Brumfitt W. Comparison of sterile bag, clean catch and suprapubic aspiration in the diagnosis of urinary infection in early childhood. $\mathrm{Br} \mathrm{J} \mathrm{Urol}$ 1976:48:279-83.

3. Dasgupta P, Haslam C, Goodwin R, et al. The 'Queen Square bladder stimulator': a device for assisting emptying of the neurogenic bladder. Br J Urology 1997;80:234237.

4. Prasad RS, Smith SJ. Wright H. Lower abdominal pressure versus external bladder stimulation to aid bladder emptying in multiple sclerosis: a randomized controlled study. Clin Rehab 2003:17:42-7.

5. Gladh G, Mattsson S, Lindström S. Intravesical electrical stimulation in the treatment of micturition dysfunction in children. Neurourol Urodyn 2003;22:233-42.

\section{BNF for Children 2007-Giving you the confidence to use children's medicines effectively}

In less than 2 years BNFC has become the leading source of paediatric drug information that is providing "reassurance" to $97 \%$ of its recipients.

For more information visit bnfc.org.

To order go to www.pharmpress.com. 
ADC

\section{Randomised trial of a vibrating bladder} stimulator - the time to pee study

P Davies, R Greenwood and J Benger

Arch Dis Child 2008 93: 423-424 originally published online January 11, 2008

doi: $10.1136 /$ adc.2007.116160

Updated information and services can be found at:

http://adc.bmj.com/content/93/5/423.full.html

These include:

References This article cites 5 articles, 2 of which can be accessed free at: http://adc.bmj.com/content/93/5/423.full.html\#ref-list-1

Email alerting Receive free email alerts when new articles cite this article. Sign up in service the box at the top right corner of the online article.

Notes

To request permissions go to:

http://group.bmj.com/group/rights-licensing/permissions

To order reprints go to:

http://journals.bmj.com/cgi/reprintform

To subscribe to BMJ go to:

http://group.bmj.com/subscribe/ 